\title{
Training adolescents with type 1 diabetes to carbohydrate counting without parents' help
}

\section{Capacitação de adolescentes com diabetes \\ tipo 1 para a contagem de carboidratos \\ sem a ajuda dos pais}

\author{
Beatriz Diniz GABRIEL ${ }^{1}$ \\ Cristiano Tulio ALBUQUERQUE² \\ Marcella Lobato Dias CONSOLI ${ }^{1}$ \\ Patrícia Amaral Fulgêncio da Cunha MENEZES ${ }^{3}$ \\ Janice Sepúlveda REIS ${ }^{1}$
}

\section{A B S T R A C T}

\section{Objective}

To develop and evaluate the effectiveness of a nutrition education program to enable adolescents with type 1 diabetes to count carbohydrates without the parents' help.

\section{Methods}

Nineteen adolescents with type 1 diabetes from a diabetes center participated in four fortnightly meetings of one hour, with lectures and discussions about healthy nutrition, importance of nutrients for blood glucose, portion sizes, food replacements, and carbohydrate counting therapy. All meetings ended with exercises to check the learning. Adolescents were followed for one year after the intervention.

\section{Results}

All participants were $100 \%$ successful in all the steps of the program and started carbohydrate counting in the main meals. Nutritional status and total daily insulin doses before and after the study did not differ. After 12 months, $68 \%$ of the adolescents counted carbohydrates at all times, $16 \%$ did so in extra snacks, and $16 \%$ were suspended from the new therapy. Eighty percent of the parents were satisfied with the program, believing teenagers were trained in the new therapy.

\footnotetext{
1 Santa Casa de Belo Horizonte, Instituto de Ensino e Pesquisa. R. Domingos Vieira, 590, Santa Efigênia, 30150-240, Belo Horizonte, MG, Brasil. Correspondência para/Correspondence to: JS REIS. E-mail: <janicesepulveda@gmail.com>.

2 Universidade Federal de Minas Gerais, Faculdade de Medicina, Departamento de Endocrinologia Pediátrica. Belo Horizonte, MG, Brasil.

3 Faculdade de Ciências Médicas de Minas Gerais, Curso de Medicina, Departamento de Endocrinologia. Belo Horizonte, MG, Brasil.

Article based on the master's thesis of BD GABRIEL, intitled "Desenvolvimento de metodologia para ensinar adolescentes com diabetes tipo 1 a contar carboidratos sem ajuda dos pais". Santa Casa de Belo Horizonte; 2012.
} 


\section{Conclusion}

A short nutrition education program successfully trained adolescents to count carbohydrates without the parents' help.

Keywords: Carbohydrate. Diabetes Mellitus type 1. Food and nutrition education.

\section{R E S U M O}

\section{Objetivo}

Desenvolver e avaliar a eficácia de um programa de educação nutricional para capacitar adolescentes com diabetes tipo 1 na contagem de carboidratos sem ajuda dos pais.

\section{Métodos}

Dezenove adolescentes com diabetes tipo 1 de um centro de diabetes participaram de quatro encontros quinzenais de uma hora, com palestras e discussões sobre alimentação saudável, importância dos nutrientes na glicemia, tamanho das porções, substituições de alimentos e contagem de carboidratos. Todos os encontros foram finalizados com exercícios para verificar o aprendizado. Os adolescentes foram acompanhados por um ano após a intervenção.

\section{Resultados}

Todos os pacientes tiveram 100\% de sucesso em todas as etapas do programa e começaram a contagem de carboidratos nas refeições principais. Não houve diferença no estado nutricional e doses totais diárias de insulina antes e depois do estudo. Após 12 meses, 68\% dos adolescentes contavam carboidratos em todas as refeições, $16 \%$ nos lanches extras, e 16\% tinham interrompido a nova terapia. Oitenta por cento dos pais estavam satisfeitos com o programa e acreditavam que os adolescentes estavam capacitados para nova terapia.

\section{Conclusão}

Após um programa de educação nutricional, de curta duração, foi possível capacitar adolescentes na contagem de carboidratos sem a presença constante dos pais.

Palavras-chave: Carboidratos. Diabetes Mellitus tipo 1. Educação alimentar e nutricional.

\section{INTRODUCTION}

Accounting for $5-10 \%$ of diabetes cases, type 1 diabetes is due to cell-mediated autoimmune destruction of pancreatic B-cells'. Its treatment includes intensive insulin therapy (multiple insulin doses), meal planning, and physical activity, which has been shown to improve glycemic control? ${ }^{2}$.

It is important to know which situations hinder adherence to dietary treatment of type 1 diabetes $^{3}$. The literature shows that a strict diet can be difficult to follow in the long term ${ }^{4}$. In this context, carbohydrate counting, nutritional therapy of choice in type 1 diabetes, allows flexible food choices, avoiding restrictive diets, and patients may consume any food in a healthy eating plan $^{5-7}$.
This therapy focuses on carbohydrate as the most important nutrient affecting postprandial glycemia. It estimates carbohydrate intake, adjusting insulin in mixed meals. This addresses the variable eating habits of children and adolescents. Carbohydrate counting allows flexible food planning, and the meal planning approach is important for the physical and psychological development of children and adolescents with diabetes ${ }^{8-10}$.

The knowledge required for using this method includes glucose monitoring, multiple insulin doses, carbohydrate targets per meal, and diabetes education. There are well established methods in the literature for training adults for this therapy, but there are no tools for adolescents ${ }^{10-12}$. Carbohydrate counting is currently trained together with parents or caregivers ${ }^{12}$. However, adolescence 
is a stage of searching independence, increasing activity without parents or caregivers, and increasing food flexibility. Furthermore, most parents work away from home and cannot follow teenagers in their daily activities. This might, in many cases, postpone this therapy ${ }^{13,14}$

Currently, studies that describe a method for teaching teenagers about carbohydrate counting do not exist. There are already methods to teach them together with the family ${ }^{12}$, and to assess the impact on glycemic control ${ }^{14}$ and counting accuracy ${ }^{10,11}$.

The purpose of this study was to develop and test a nutrition education program that empowers adolescents with type 1 diabetes to count carbohydrates independently, without the parents' help.

\section{METHODS}

Participants in this quasi-experimental study (pre and post intervention) were recruited from a diabetes center in Belo Horizonte, Minas Gerais, Brazil. The inclusion criteria were adolescents with type 1 diabetes aged 10 to 14 years of both sexes; diabetes duration of at least 12 months; basic knowledge in mathematics according to the appropriate school grade/age; no experience in carbohydrate counting; self-administration of insulin, and glucose monitoring without the parents' help. Twenty-four adolescents accepted to participate (corresponding to the total number of adolescents aged 10 to 14 years who were not in carbohydrate counting in diabetes center) and 19 completed the study (five were excluded for attending only the first meeting and reporting unavailability to participate in all the meetings).

The patients were evaluated at baseline and after 12 months of intervention. The family was informed that only the teen should participate in the meetings. When in doubt, patients and family could contact the health team. The ethics committee of Santa Casa of Belo Horizonte Hospital approved the Protocol ( $n^{\circ}$ 06281012.7.0000.5138), and all children and their parents provided Informed Written Consent.

Participants received a calculator, notepad, pen, carbohydrate counting manual, list of food substitutions, and menu appropriate for age and sex, calculated according to the estimated energy requirement.

Height and weight were determined at baseline and after 12 months. Body weight was determined to the nearest $0.1 \mathrm{~kg}$ by standard physician's beam scales, with the child wearing only underwear and no shoes. Height was measured to the nearest $0.1 \mathrm{~cm}$ on standardized, wall-mounted height boards. Body Mass Index (BMI) was calculated as weight (kilograms) divided by height (meters) squared. The standard deviation BMI score (Z-score) was also calculated. The same investigator measured the height and weight of each patient three times and calculated the mean for the analyses.

This study consisted of 3 phases: 1) development and test of an education program based on international guidelines and national Reference Dietary Intakes ${ }^{15-17}$, 2) immediate evaluation of program success, and 3) follow-up.

All participants participated in a nutrition education program consisting of four fortnightly meetings lasting 60 minutes each, with lectures and discussions about the right use of carbohydrate counting based on the guidelines and materials used in clinical practice for this therapy ${ }^{18,19}$. All meetings were held by the same dietitian. Dietary education tools were selected carefully to achieve maximum understanding and adherence (Chart 1).

After the fourth meeting, patients who achieved $100 \%$ accuracy with respect to carbohydrate quantification in the menu received from the medical team an insulin/carbohydrate ratio (amount of insulin needed to cover the carbohydrate intake) to start carbohydrate counting in extra snacks (all meals off the meal plan). Extra snacks should be consumed at least three times a week and had to be $100 \%$ correct 
Chart 1. Diabetes Education Program. Belo Horizonte (MG), Brazil.

\section{First meeting}

Discussion about nutrition and healthy weight, food pyramid, daily caloric needs, nutrients and their importance, the effects of these nutrients on blood glucose, weight and cooking weights and measures, concepts of grams and portions, and equivalents and food substitutions.

Activity: To complete the food pyramid with food molds. Each participant explained his choice of food and the group discussed it. The most commonly used utensils in the household should be present to compare the sizes of portions used in everyday life.

Second meeting

Concepts of basal and bolus insulin, insulin/carbohydrate ratio, technique of carbohydrate counting, carbohydrate counting table, and food labels.

Activity: In pairs, participants were instructed to give examples of meals with goals of 30, 45, and 60 grams of carbohydrates. They chose the food and amounted to the total carbohydrate content of the meal. In group, they checked food labels for cookies and breads to identify the most important nutrition information. Final discussions on carbohydrate content and portion sizes.

\section{Third meeting}

Use of educational materials in the form of slides, with pictures representing each food group on the food pyramid, with questions about the group and their equivalents for discussions.

Activity: In pairs, they should create a list of replacements for foods with utensils that were used at home. Discussions about the food groups based on the pyramid presented at meeting 1, working list of replacements for food trade.

Fourth meeting

Each participant was provided with a reproducible meal plan individually calculated with several food options that could easily be maintained to quantify carbohydrates. Awareness of proper serving sizes of food, particularly those containing carbohydrates, was emphasized. Final discussions and questions.

because any mistake could result in severe hypoglycemia or hyperglycemia. It begins with extra snacks as another way to assess whether the patient was able to correctly understand the concept of the new therapy. The foods consumed in extra snacks and insulin dose was recorded by the patients.

Fifteen days after the last meeting, all patients were evaluated individually to verify the extra snacks' calculations and whether they were able to start the new therapy for all meals. The dietician, together with the patients, carefully reviewed the food records to ensure that the participants provided an adequate level of detail in describing food and food preparation methods. The main points and doubts were discussed. Participants who achieve 100\% accuracy in this phase started carb counting at every meal, according to the prescription of the pediatric diabetologist.

After 30 days, there was a telephone contact with the patient to evaluate difficulty or doubt, check episodes of severe hypoglycemia or error in calculations of insulin doses, obtain information about the total daily insulin dose used, and verify provision for carbohydrate counting at all times or only in extra snacks.

At the end of the study, a satisfaction survey was conducted with parents about the new treatment, with two yes-no questions: "In your opinion, is your child able to continue the therapy?"; "Are you satisfied with your child's new treatment?".

The data were analyzed by the software Statistical Package for the Social Sciences (SPSS, Inc., Chicago, Illinois, United States) version 17.0. Data are expressed as mean and standard deviation. The Student's $t$ test for paired data assessed the difference between variables measured at baseline and at follow-up. The Chisquare or Fisher's exact test was used when the number of cells in the contingency table had fewer than five observations. A $p<0.05$ was considered statistically signicant. 


\section{R E S U L T S}

Nineteen teenagers divided into three groups of five, six, and eight individuals participated in all activities. Table 1 shows their clinical and anthropometric characteristics. BMI and total daily insulin dose at baseline and 12 months after the initiation of carb counting did not differ.

In Activity 1 of the nutrition education program, the teens completed the food pyramid. In Activity 2 all patients gave examples of menus with the suggested goals of carbohydrates per meal and then corrected the activity in pairs. No questions were presented to verify the carbohydrate content of foods in the manual. In label assessment, the patients had difficulties to understand portion size and percentage of daily caloric value, and all questions were answered. Then the participants reevaluated the labels commonly used daily to consolidate learning.

Activity 3 used educational slides to show the food groups discussed in Activity 1 with the mount of the food pyramid. They managed to make food substitutions using the list of replacements. In Activity 4 only one patient did not quantify carbohydrates with 100\% accuracy. His mistake was not quantifying the total carbohydrate content of the tablespoons of rice and beans contained in the menu. New individual training was offered, for 1 hour, before continuing the activities.

At the end of the fourth and final meeting, where all patients reached $100 \%$ accuracy, the patients received from the medical team their insulin/carbohydrate ratio for the initiation of therapy in extra snacks.

After 15 days, all patients had hit 100\% accuracy in the measurement of extra snacks and started to count carbohydrates in all the main meals (breakfast, lunch, and supper).

In the follow-up on day 30, the patients reported no mistake that resulted in severe hypoglycemia. Only two patients $(10 \%)$ had difficulties finding foods in the manual. They were instructed to read the labels in case of commercially processed foods or find similar preparations in the manual.

In terms of parental satisfaction with the treatment, $80 \%$ said that the teenager was able to follow the new therapy, and $92 \%$ were pleased with the new treatment.

After 12 months, 13 (68\%) patients counted carbohydrates at all times and 3 (16\%) did so in extra snacks. The medical staff suspended the new treatment in $3(16 \%)$ patients because of noncompliance.

Table 1. Clinical and anthropometric characteristics at baseline and after 12 months of follow-up. Belo Horizonte (MG), Brazil, 2013.

\begin{tabular}{|c|c|c|c|}
\hline Characteristic & Baseline $(n=19)$ & After 12 months $(n=19)$ & $p^{*}$ \\
\hline \multicolumn{4}{|l|}{ Sex } \\
\hline Male & 6 & - & - \\
\hline Female & 13 & - & - \\
\hline Age (years) & $12.0 \pm 1.30$ & $14.0 \pm 1.3$ & $>0.05$ \\
\hline Duration of diabetes (months) & $47.0 \pm 30.00$ & $66.0 \pm 30.4$ & $>0.05$ \\
\hline Body mass index $\left(\mathrm{kg} / \mathrm{m}^{2}\right)$ & $20.2 \pm 4.28$ & $22.1 \pm 4.5$ & $>0.05$ \\
\hline Very low weight & (1) $\quad(5 \%)$ & $(-) \quad(0 \%)$ & $>0.05$ \\
\hline Normal & (13) $(69 \%)$ & (17) $(90 \%)$ & $>0.05$ \\
\hline Overweight & ( 0$) \quad(0 \%)$ & (1) $(5 \%)$ & $>0.05$ \\
\hline Obesity & (4) $(21 \%)$ & (0) $\quad(0 \%)$ & $>0.05$ \\
\hline Severe obesity & (1) $\quad(5 \%)$ & (1) $(5 \%)$ & $>0.05$ \\
\hline Total insulin requirement (kg/day) & $0.9 \pm 0.3$ & $1.0 \pm 0.3$ & $>0.05$ \\
\hline
\end{tabular}

Note: * $p<0.05$ was considered statistically signicant. Data are shown as mean and standard deviation or $\mathrm{n}(\%)$. 


\section{DISCUSSION}

Diabetes self-management education and diabetes self-management support are the processes of facilitating knowledge for diabetes self-care. This process involves learning, skills' training, and life experiences of people with diabetes. The goals are to support informed decision making, self-care behaviors, and active collaboration with the health care team to improve glycemic control and quality of life ${ }^{20}$.

Carbohydrate counting is the nutritional therapy of choice in type 1 diabetes $^{6}$ and is usually delayed for convenience because of the difficulties faced by parents and caregivers to follow children and adolescents in treatment. In this context, diabetes self-management education is the key to solutions that can contribute to the health team, better control, and quality of life.

Dealing with adolescents is a challenge because adolescence is a phase of intensive physical, psychological, and sociocultural changes, and there is no established methodology in the literature to educate these patients alone. This group has learning peculiarities. For this reason, the themes of the meetings were more dynamic with lectures and exercises with mutual correction, a way to better capture attention and consolidate learning.

The choice of topics was based on the knowledge that patients need to have before carbohydrate counting. These topics are commonly transmitted to parents and patients during consultations until the start of the therapy. No difficulties have been found during the study to justify the inclusion or exclusion of any subject. There was no change in nutritional status before and after the study. This suggests that patients did not abuse food flexibility and used the carbohydrate counting in a healthy eating plan.

According to the theory proposed by Vygotsky ${ }^{21}$, group interaction is an exchange of experiences in the acquisition of learning. The organization of meetings was useful because adolescents interacted and were more relaxed to ask questions without fear. According to Piaget ${ }^{22}$, individuals older than 7 years begin to develop logic and understand the nature of things, acquiring the ability to perform mental operations.

Studies suggest that new methods of education motivate patients with diabetes ${ }^{23}$. During the meetings, the teens' disposition for the proposed learning as well as the enthusiasm and joy of being an active subject in control of their diabetes were visible. Diabetes education in adolescence can facilitate health care.

The insulin requirement at baseline and 12 months after training did not change, and no severe hypoglycemia was recorded. According to this, subjects who received standard nutrition education and training to estimate the carbohydrate content of a meal to better calculate insulin doses can better avoid the risk of excess insulin.

Most parents were satisfied with the new treatment. It is possible that the idea of shared responsibility with the teenager, not depriving food flexibility, was their biggest motivator. For the medical team, this was a successful result because 16 (84\%) the patients remain in the new therapy after 1 year.

\section{CONCLUSION}

The present study demonstrated that after a short nutrition education program adapted to the needs of this age group, teenagers could count carbohydrates successfully without the constant presence of the parents. Diabetes education plays a vital role to improve treatment quality.

\section{CONTRIBUTORS}

BD GABRIEL contributed to the study design, data collection, analysis and interpretation of the results, writing, reviewing and final approval of the manuscript. CT ALBUQUERQUE and PAFC MENEZES contributed to the study design, data collection, and analysis and interpretation of the results. MLD CONSOLI guided the analysis and interpretation of the results. JS REIS guided data collection, analysis, and interpretation of the results, and writing of the manuscript. 


\section{REFERENCES}

1. American Diabetes Association. 2. Classification and diagnosis of diabetes. Diabetes Care. 2015; 38(Suppl.):S8-S16. http://dx.doi.org/10.2337/dc15-S 005

2. Dose Adjustment For Normal Eating. Study Group. Training in flexible, intensive insulin management to enable dietary freedom in people with type 1 diabetes: Dose Adjustment For Normal Eating (DAFNE) randomised controlled trial. BMJ. 2002; 325(7367): 746.

3. Schlundt DG, Quesenberry L, Pichert JW, Wolf J, Ray S, Lorenz RA, et al. Evaluation of a training program for improving adherence-promotion skills of dietetic interns. J Am Diet Assoc. 1994; 94(12): 1421-5.

4. Mehta SN, Volkening LK, Anderson BJ, Nansel T, Weissberg-Benchell J, Wysocki T, et al. Dietary behaviors predict glycemic control in youth with type 1 diabetes. Diabetes Care. 2008; 31(7):1318-20. http://dx.doi.org/10.2337/dc07-2435

5. Bantle JP, Wylie-Rosett J, Albright AL, Apovian CM, Clark NG, Franz MJ, et al. Nutrition recommendations and interventions for diabetes: A position statement of the American Diabetes Association. Diabetes Care. 2008; 31(Suppl. 1):S61-78. http://dx.doi.org/ 10.2337/dc08-S061

6. Kawamura T. The importance of carbohydrate counting in the treatment of children with diabetes. Pediatr Diabetes. 2007; 8(Suppl. 6):57-62. http:// dx.doi.org/10.1111/j.1399-5448.2007.00287.x

7. American Diabetes Association. 4. Foundations of care: Education, nutrition, physical activity, smoking cessation, psychosocial care, and immunization. Diabetes Care. 2015; 38(Suppl.):S20-30. http://dx. doi.org/10.2337/dc15-S007

8. Mehta SN, Quinn N, Volkening LK, Laffel LM. Impact of carbohydrate counting on glycemic control in children with type 1 diabetes. Diabetes Care. 2009; 32(6):1014-6. http://dx.doi.org/10.2337/dc08-2068

9. Brazeau AS, Mircescu H, Desjardins K, Leroux C, Strychar I, Ekoe JM, et al. Carbohydrate counting accuracy and blood glucose variability in adults with type 1 diabetes. Diabetes Res Clin Pract. 2013; 99(1):19-23. http://dx.doi.org/10.1016/j.diabres. 2012.10.024

10. Smart CE, Ross K, Edge JA, King BR, McElduff $P$, Collins CE. Can children with Type 1 diabetes and their caregivers estimate the carbohydrate content of meals and snacks? Diabet Med. 2010; 27(3): 348-53. http://dx.doi.org/10.1111/j.1464-5491.20 10.02945.x

11. Waldron S, Hanas R, Palmvig B. How do we educate young people to balance carbohydrate intake with adjustments of insulin? Horm Res. 2002; 57(Suppl. 1): 62-5.
12. Spiegel G, Bortsov A, Bishop FK, Owen D, Klingensmith GJ, Mayer-Davis EJ, et al. Randomized nutrition education intervention to improve carbohydrate counting in adolescents with type 1 diabetes study: Is more intensive education needed? J Acad Nutr Diet. 2012; 112(11):1736-46. http:// dx.doi.org/10.1016/j.jand.2012.06.001

13. Chaney D, Coates V, Shevlin M, Carson D, McDougall A, Long A. Diabetes education: What do adolescents want? J Clin Nurs. 2012; 21(1-2): 216-23. http://dx.doi.org/10.1111/j.1365-2702. 2010.03692.x

14. Wylie-Rosett J, Aebersold K, Conlon B, Ostrovsky NW. Medical nutrition therapy for youth with type 1 diabetes Mellitus: More than carbohydrate counting. J Acad Nutr Diet. 2012; 112(11):1724-7. http://dx.doi.org/10.1016/j.jand.2012.07.033

15. American Diabetes Association. Standards of medical care in diabetes-2015: Summary of revisions. Diabetes Care. 2015; 38(Suppl.):S4. http:// dx.doi.org/10.2337/dc15-S003

16. Rosenbloom AL, Silverstein JH, Amemiya S, Zeitler $P$, Klingensmith GJ. ISPAD Clinical Practice Consensus Guidelines 2006-2007. Type 2 diabetes Mellitus in the child and adolescent. Pediatr Diabetes. 2008; 9(5):512-26. http://dx.doi.org/ 10.1111/j.1399-5448.2008.00429.x

17. Health Canada. Dietary Reference Intakes. Otawa: Health Canada; 2005 [cited 2013 Aug 13]. Available from: http://www.hc-sc.gc.ca/fn-an/nutrition/ reference/table/index-eng.php

18. Brown SA. Interventions to promote diabetes selfmanagement: State of the science. Diabetes Educ. 1999; 25(6 Suppl.):52-61.

19. Sociedade Brasileira de Diabetes. Departamento de Nutrição. Manual oficial de contagem de carboidratos regional. Rio de Janeiro: Sociedade Brasileira de Diabetes; 2009.

20. Haas L, Maryniuk M, Beck J, Cox CE, Duker P, Edwards $L$, et al. National standards for diabetes self-management education and support. Diabetes Care. 2014; 37(Suppl. 1):S144-53. http://dx.doi.org/ 10.23 37/dc14-S144

21. Vygotsky L. Pensamento e linguagem. São Paulo: Martins Fontes; 1987.

22. Piaget J. A epistemologia genética/sabedoria e ilusões da filosofia: problemas de psicologia genética. São Paulo: Abril Cultural; 1983.

23. Lange K, Swift P, Pankowska E, Danne T. Diabetes education in children and adolescents. Pediatr Diabetes. 2014; 15(Suppl. 20):77-85. http://dx.doi. org/10.1111/pedi.12187

Received: January 29, 2015

Final version: August 19, 2015

Approved: September 22, 2015 
